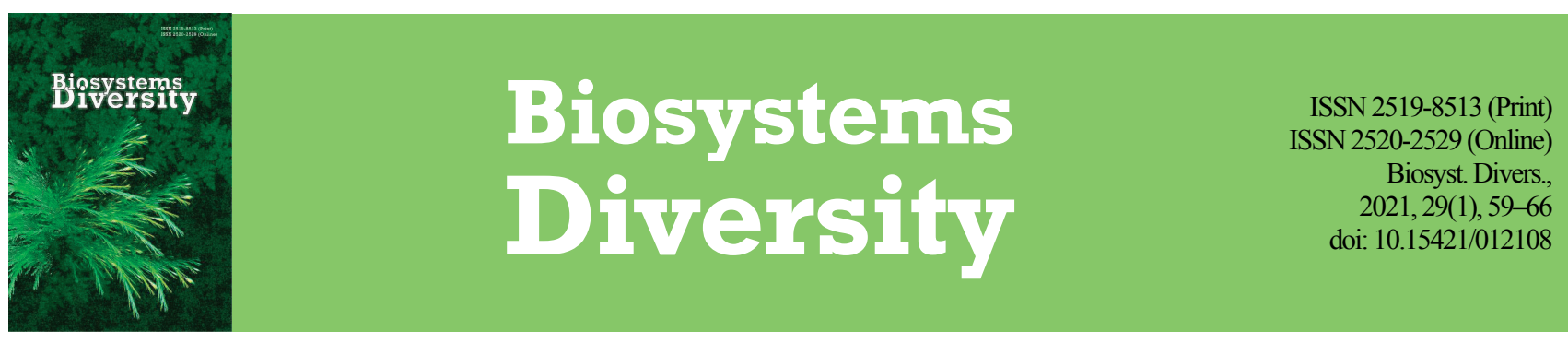

\title{
Algal and cyanobacterial diversity in saline rivers of the Elton Lake Basin (Russia) studied via light microscopy and next-generation sequencing
}

\author{
M. E. Ignatenko, E. A. Selivanova, Y. A. Khlopko, T. N. Yatsenko-Stepanova \\ Institute for Cellular and Intracellular Symbiosis of the Ural Branch of the Russian Academy of Sciences, Orenburg, Russia
}

Article info

Received 16.01.2021

Received in revised form 20.02.2021

Accepted 22.02.2021

Institute for Cellular

and Intracellular Symbiosis

of the Ural Branch

of the Russian Academy

of Sciences,

Pionerskaya st., 11,

Orenburg, 460000, Russia.

Tel.: +7-353-277-54-17

E-mail:

ignatenko_me@mail.ru

Ignatenko, M. E., Selivanova, E. A., Khlopko, Y. A., \& Yatsenko-Stepanova, T. N. (2021). Algal and cyanobacterial diversity in saline rivers of the Elton Lake Basin (Russia) studied via light microscopy and next-generation sequencing. Biosystems Diversity, 29(1), 59-66. doi:10.15421/012108

Naturally saline rivers are known in various regions of the world. Saline rivers with a salinity gradient from the source to the mouth are particularly interesting, because the range of salinity is the structure-forming factor of the hydrobiont assemblage. Such rivers are represented by saline rivers of the Elton Lake Basin in Volgograd region of Russia (the Bolshaya Samoroda River and the Malaya Samoroda River). Herein, we analyzed taxonomic structure and species diversity of microalgae and Cyanobacteria of the saline rivers flowing into the Elton Lake by light microscopy and next-generation sequencing. The differences and possible causes of inconsistencies in the results obtained by these methods are discussed. In total, 91 taxa of microorganisms were identified by integrated approach in the assemblages of microalgae and Cyanobacteria in the middle course of the Bolshaya Samoroda River, and 60 taxa - in the river mouth. The species diversity of those assemblages in the hypersaline Malaya Samoroda River was lower: 27 taxa from the middle course and 23 taxa from the mouth. Next-generation sequencing allowed us to refine and expand the list of microalgae taxa in the studied saline rivers due to detection of species which were hard to identify, low-abundance taxa, as well as extremely small-cell forms. Some discrepancies between the data obtained by light microscopy and next-generation sequencing indicate the advantage of simultaneous use of both methods for study of the algae communities. Such a comprehensive approach provides the most accurate and correct list of taxa added with the morphological descriptions and 18S rRNA and 16S rRNA partial sequences. Generally, 18 taxa have been recorded for the first time in the Bolshaya Samoroda River, belonging to the phyla Chlorophyta (Borodinellopsis sp., Chlorochytrium lemnae Cohn, Caespitella sp., Halochlorococcum sp., Tetraselmis cordiformis (H. J. Carter) F. Stein), Ochrophyta (Pseudocharaciopsis ovalis (Chodat) D. J. Hibberd, Characiopsis sp., Poterioochromonas stipitata Scherffel, Chrysolepidomonas sp.), Euglenozoa (Euglena bucharica I. Kisselev, Lepocinclis tripteris (Dujardin) B. Marin \& Melkonian, Phacus orbicularis K. Hübner, P. parvulus G. A. Klebs), Cryptophyta (Hemiselmis cryptochromatica C. E. Lane \& J. M. Archibald, Rhodomonas sp., Hanusia phi J. A. Deane), Haptophyta (Pavlova sp.), Cyanobacteria (Johanseninema constrictum (Szafer) Hasler, Dvorák \& Poulícková). Seven taxa have been detected for the first time in the algal and cyanobacterial assemblages of the Malaya Samoroda River from the phyla Chlorophyta (Tetraselmis cordiformis, T. arnoldii (ProschkinaLavrenko) R. E. Norris, Hori \& Chihara, T. tetrathele (West) Butcher, Pyrobotrys elongatus Korshikov), Cryptophyta (Hanusia phi), and Cyanobacteria (Synechococcus elongatus (Nägeli) Nägeli, Oscillatoria simplicissima Gomont).

Keywords: microalgae; Cyanobacteria; saline rivers; Elton; light microscopy; next-generation sequencing.

\section{Introduction}

Water bodies with naturally high levels of salinity are widely distributed on all continents of the globe and are the objects of numerous scientific studies (Heidelberg et al., 2013; Afonina \& Tashlykova, 2016). The increased attention paid to saline waterbodies is primarily due to the development of specific biota in them, represented by halotolerant and halophilic species, many of which are of biotechnological importance as producers of biologically active substances (Solovchenko et al., 2015; Mohammadi et al., 2015; Almutairi \& Toulibah, 2017).

Among the various types of mineralized water bodies, saline rivers are by far the least studied (Orfeo, 1999; Burkova, 2015; Gutiérrez-Cánovas et al., 2019). Saline rivers with a salinity gradient from the source to the mouth are particularly interesting, because the range of salinity is the structure-forming factor of the hydrobiont assemblage (Telesh et al., 2013; Zinchenko et al., 2017). Such rivers are represented by saline rivers, which flow into the largest hypersaline lake in Europe - Lake Elton (Volgograd region, Russia). These watercourses are actively studied. Information about the structure of the assemblage of autotrophic protists of the saline rivers in the Elton region is given in a number of publications (Gorokhova \& Zinchenko, 2014, 2016; Burkova, 2015; Yatsenko-Stepanova et al., 2015). However, all the studies carried-out were based solely on the morphological approach using the methods of light microscopy. At the same time, the application of the molecular methods that use the techniques of next-generation sequencing in the study of diatom assemblages of the brackish Bolshaya Samoroda River demonstrated the need to use an integrated approach, including both morphological and molecular methods (Selivanova et al., 2019).

An integrated approach allows us to overcome certain shortcomings of the morphological method, which are pointed out by a number of authors, and which can affect the final result of the work (Zhan et al., 2013; Manoylov, 2014, 2016; Groendahl et al., 2017). For example, researchers often face difficulties in identifying small-cell species of algae (Belevich et al., 2015); species diversity is often underestimated or overestimated due to phenotypic variability (Kulikovskiy et al., 2014; Rivera et al., 2018a, b). DNA barcoding is a modern approach, which can make it possible to solve this problem (Kim et al., 2014; Belevich et al., 2015; Medlin, 2018). Currently, the number of studies using molecularbased methods to assess the species richness and diversity of natural assemblages of autotrophic protists from different types of habitats is growing exponentially (Gao et al., 2018; Palinska et al., 2018; Wangensteen et al., 2018). Techniques of next-generation sequencing are considered as the most promising (Groendahl et al., 2017; Oliveira et al., 2018; Pawlowski et al., 2018). In this study, we made an attempt to assess the diversity and assemblage structure of microalgae and Cyanobacteria of the two saline rivers of the Elton Lake Basin (Malaya Samo- 
roda River, Bolshaya Samoroda River) by light microscopy (LM) and next-generation sequencing (NGS).

\section{Materials and methods}

Water samples were taken in the middle course and mouth of Malaya Samoroda River and Bolshaya Samoroda River in August 2014. Due to the significant shallowing in summer, no samples were taken in the upper course of the rivers. The Malaya Samoroda and Bolshaya Samoroda Rivers flow into the largest hypersaline lake in Europe - Lake Elton (Lake Elton Biosphere Reserve, Russia, a UNESCO World Heritage site) (Fig. 1). These rivers are shallow lowland watercourses with slow current
(0-0.20 m/s). The Bolshaya Samoroda River has a length of 21-24 km, the catchment area is $130.0 \mathrm{~km}^{2}$, the channel is $6.0-35.0 \mathrm{~m}$ wide, the depth varies from 0.10 to $0.70 \mathrm{~m}$ (Gusakov, 2019). The salinity level of the river (at the time of sampling) increased from the middle course (10 ppt) to the mouth (19 ppt). The length of the Malaya Samoroda River is $10.3 \mathrm{~km}$, the catchment area is $48.7 \mathrm{~km}^{2}$, the channel is $15.0-50.0 \mathrm{~m}$ wide, and the depth is $0.05-0.25 \mathrm{~m}$ (Gusakov, 2019). The salinity level (at the time of sampling) both in the middle course and in the mouth was constant and reached 85 ppt. Salinity was measured using a Master S-28a portable refractometer (Atago, Japan). The Bolshaya Samoroda River was classified as mixohaline (middle course - mesohaline, mouth - polyhaline), the Malaya Samoroda River is hypersaline according to the Venice system (1958).

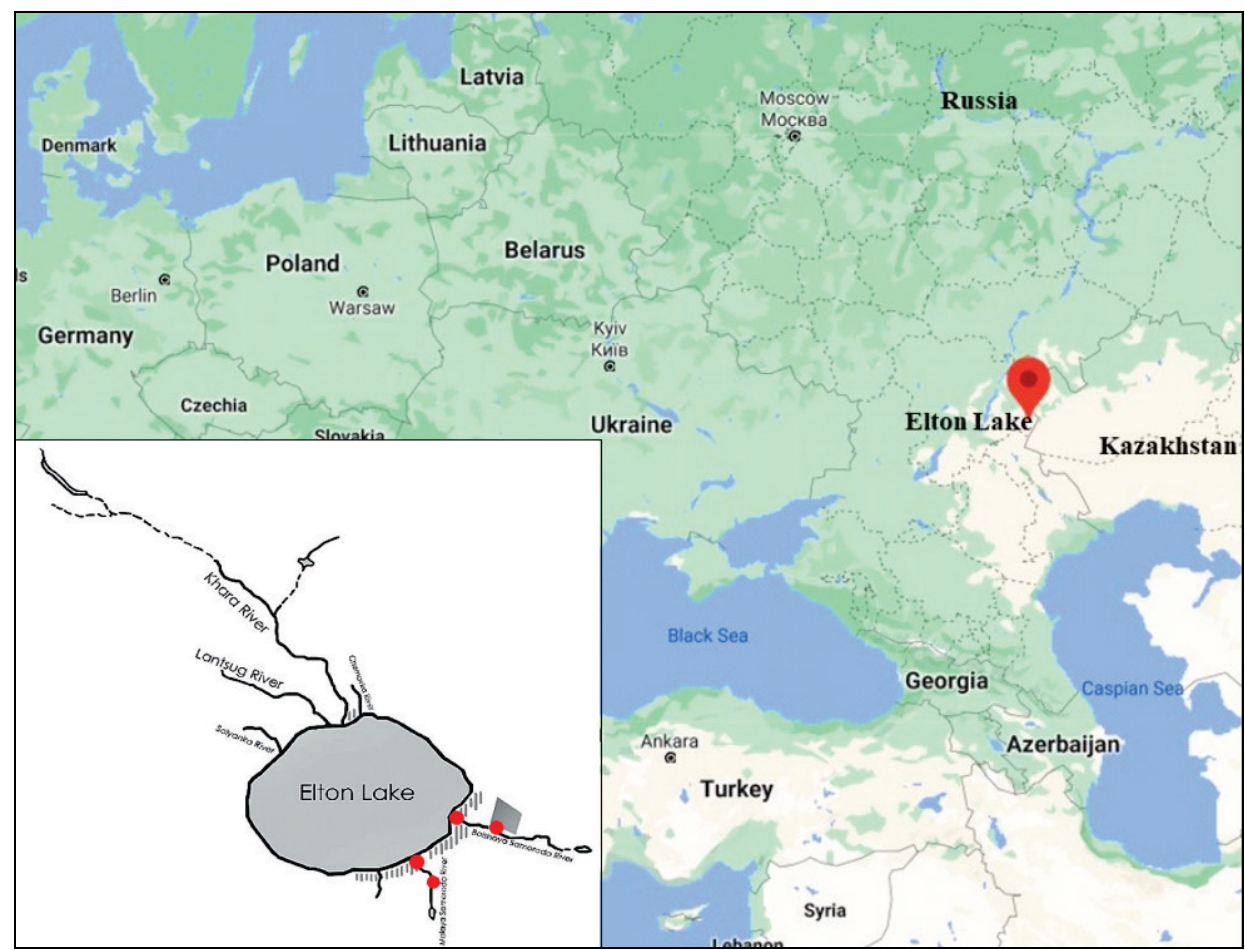

Fig. 1. Scheme of the Elton Lake Basin with sampling sites marked with red dots

(Bolshaya Samoroda River: middle course $49.208889^{\circ} \mathrm{N}, 46.941111^{\circ} \mathrm{E}$, river mouth $49.283333^{\circ} \mathrm{N}, 47.036944^{\circ} \mathrm{E}$;

Malaya Samoroda River: middle course $49.146648^{\circ} \mathrm{N}, 46.676354^{\circ} \mathrm{E}$, river mouth $49.096050^{\circ} \mathrm{N}, 46.731250^{\circ} \mathrm{E}$ )

Water samples of $0.5 \mathrm{~L}$ were fixed with a solution of $40 \%$ formaldehyde. The treatment of the samples was performed according to the methods generally accepted in hydrobiology (Vasser et al., 1989). For algae identification the articles (Massjuk \& Lilitska 2006; Hasler et al., 2012; Komarek et al., 2014) and qualifiers (Tsarenko, 1990; Krammer \& Lange-Bertalot, 1986-1991; Krakhmalny, 2011) were used. Taxonomy and nomenclature are given according to the on-line database Algaebase (Guiry \& Guiry, 2021).

Algal and cyanobacterial cells were counted in a Nageotte Counting Chamber (Assistant, Germany) with a volume of $1.25 \mathrm{~mm}^{3}$ at $400 \times$ magnification under the light microscopes "Axiostar plus", "Axioskop" (Carl Zeiss, Germany). Dominant species were determined based on their occurrence and abundance according to the dominance index (Di) (Shitikov et al., 2003). At the same time, the dominant species were those whose dominance index values varied within $10<\mathrm{Di}<100$, subdominant $-1<$ $\mathrm{Di}<10$, first-order subdominants $-0.1<\mathrm{Di}<1$ and secondary members $0.01<\mathrm{Di}<0.1$. The comparison of the diversity of microalgae and Cyanobacteria was carried out using the interactive tool Venny 2.1 (Lin et al., 2016). Micrographs of the dominant algae species were performed using light and phase-contrast microscopy at the "Axiocam" digital camera (Carl Zeiss, Germany) at $400 \times$ and $1000 \times$ magnification.

Water samples of $500 \mathrm{~mL}$ were taken and filtered through membranes with $0.45 \mu \mathrm{m}$ pore size. Total genomic DNA was isolated from the filters by a combined method, including mechanical homogenization and chemical extraction (Liu et al., 2009) in modification of Bel'kova et al. (2008). A lysing matrix E (MP Biomedicals, USA) and $400 \mu \mathrm{L}$ of Tris- salt buffer (20 mM EDTA, 750 mM NaCl, 100 mM Tris-HCl, pH 8.0) were added in every sample. The samples were homogenized in Tissue Lyser LT (QIAGEN, Germany) for $1 \mathrm{~min}$ at $50 \mathrm{~Hz}$. Then $50 \mu \mathrm{L}$ of a sterile lysis buffer with lysozyme $(50 \mu \mathrm{g} / \mathrm{mL})$ were added and the samples were incubated for $60 \mathrm{~min}$ at $37^{\circ} \mathrm{C}$, followed by addition of $10 \mu \mathrm{L}$ proteinase $\mathrm{K}(10 \mathrm{mg} / \mathrm{mL})$ and $10 \%$ sodium dodecyl sulfate up to $1 \%$ in a final volume. The mixtures were incubated for $60 \mathrm{~min}$ at $60^{\circ} \mathrm{C}$. After extraction with phenol-chloroform-isoamyl alcohol (25:24:1) and chloroformisoamyl alcohol (24:1), DNA in the aqueous phase was precipitated overnight at $-20{ }^{\circ} \mathrm{C}$ with threefold volume of anhydrous ethanol and $10 \mathrm{M}$ ammonium acetate added up to $10 \%$ of a final volume. After centrifuging and double washing with $80 \%$ ethanol, DNA was air-dried and dissolved in autoclaved MQ water. To assess contamination during DNA extracting, a negative control containing $100 \mu \mathrm{L}$ of autoclaved MQ water was subjected to the same procedure. DNA was checked with electrophoresis in 1.5\% agarose gel. The DNA concentration was quantified using Qubit 2.0 Fluorometer (Life Technologies, USA) with dsDNA High Sensitivity Assay (Life Technologies, USA).

Preparing of DNA libraries and NGS. DNA libraries were prepared according to Illumina workflow (http://support.illumina.com/documents/ documentation/chemistry_documentation/16s/16s-metagenomic-libraryprep guide-15044223-b.pdf) with primers targeting the V4 region of the 18S rRNA gene: forward TAReuk454FWD1 and reverse TAReukRev3 and with primers to the variable region V3-V4 of the 16S rRNA gene SD-Bact-0341-b-S-17 and S-D-Bact-0785-a-A-21 b (Klindworth et al., 2013). 
Sequencing was performed on a MiSeq sequencer (Illumina, USA) using MiSeq Reagent v3 reagent kit for paired-end sequencing $2 \times 300 \mathrm{bp}$ in the Center of Shared Scientific Equipment "Persistence of Microorganisms" of the Institute for Cellular and Intracellular Symbiosis of the Ural Branch of the Russian Academy of Sciences.

Paired-end reads were merged with a minimal overlap of $40 \mathrm{bp}$ and a p-value of 0.0001 using PEAR v. 0.9.10 (Zhang et al., 2014). Evaluation of the filtering quality was carried out with FastQC v.0.11.7. Quality filtering and amplicon size selection (300 bp - minimal size for the 18S rRNA gene, $420 \mathrm{bp}$ - minimal size for the 16S rRNA gene) were conducted using USEARCH v.9 (Edgar, 2013). During the filtering reads with Ns or an overall mean, Q-score $<20$ were discarded. As a result of dereplication and clustering with USEARCH, operational taxonomic units (OTUs) were formed, while singletons and doubletons were removed. OTUs were clustered using a similarity threshold of $97 \%$ between sequences to classify microorganisms at the species level. Chimeric sequences were detected and removed using USEARCH during the clustering phase.

\section{Results}

Morphological and genetic diversity of microalgae and Cyanobacteria of the Bolshaya Samoroda River. 91 taxa of microorganisms were identified in the assemblage of microalgae and Cyanobacteria of the middle course of the Bolshaya Samoroda River while using an integrated approach. Of this number, 87 taxa were autotrophic protists belonging to the phyla Bacillariophyta, Chlorophyta, Ochrophyta, Cryptophyta, Euglenozoa, Miozoa, Haptophyta, and 4-Cyanobacteria.

Morphological and genetic diversity of microalgae of the Bolshaya Samoroda River. According to the results of morphological analysis, representatives of only three phyla were found: Bacillariophyta (24 taxa ranked below the genus), Euglenozoa (5) and Chlorophyta (1). Among them, Bacillariophyta prevailed both in species diversity and in quantity, accounting for $96.2 \%$ of the total abundances of the assemblage. According to the NGS data, in DNA libraries from the river middle course sample was also dominated by OTUs belonging to the Bacillariophyta (31 OTUs, $80.3 \%$ of the total number of reads). In addition, OTUs of the phylum Chlorophyta (20 OTUs), as well as of the phyla Ochrophyta (8 OTUs), Cryptophyta (7 OTUs), Miozoa (2 OTUs), Haptophyta (1 OTU) were recorded (Fig. 2, 3).

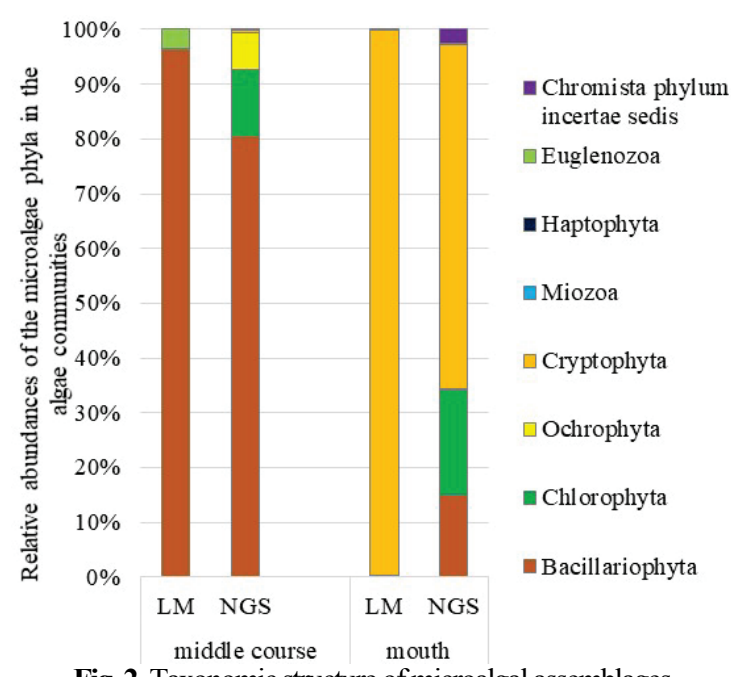

Fig. 2. Taxonomic structure of microalgal assemblages in the Bolshaya Samoroda River: LM - light microscopy, NGS - next-generation sequencing

It should be noted that the representatives of only few taxa were found by both NGS and LM. These include Surirella striatula Turpin, S. ovalis Brébisson, Tabularia fasciculata (C. Agardh) D. M. Williams \& Round, Rhoicosphenia abbreviata (C. Agardh) Lange-Bertalot, Cyclotella meneghiniana Kützing, Amphora commutata Grunow, Halamphora coffeiformis (C. Agardh) Levkov, Tryblionella apiculata W. Gregory (C. Agardh) Lange-Bertalot, Gomphonema parvulum (Kützing) Kützing, Pleurosigma sp., Tetraselmis sp.

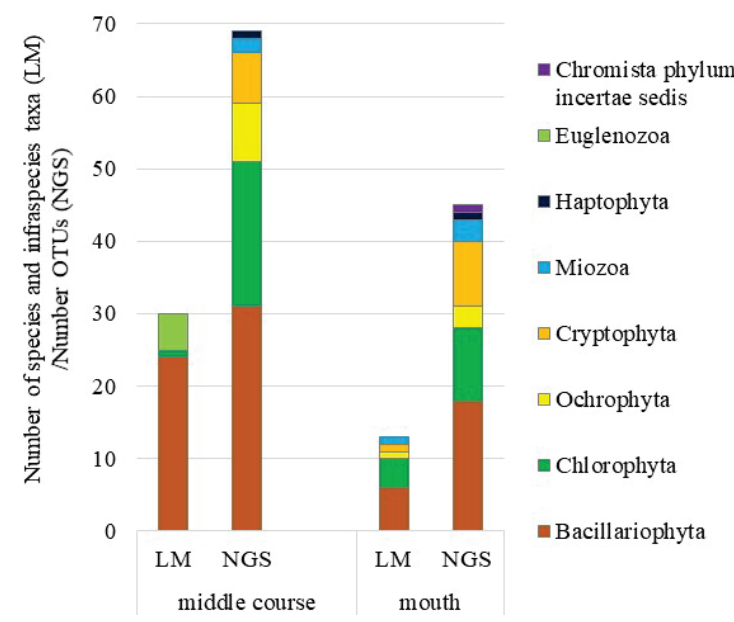

Fig. 3. Species diversity of microalgal assemblages in the Bolshaya Samoroda River: LM - light microscopy, NGS - next-generation sequencing

The complex of dominant species identified by the LM and NGS differed significantly. Thus, according to the LM data, Hippodonta hungari$c a$ (Grunow) Lange-Bertalot, Metzeltin \& Witkowski (= Navicula capitata var. hungarica (Grunow) R. Ross) (64.7\% of the total abundance) and Tryblionella hungarica (Grunow) Frenguelli (= Nitzschia hungarica Grunow) $(12.0 \%)$ were predominant (Fig. $4 \mathrm{~b}-\mathrm{d})$. The group of subdominants included T. fasciculata, Fragilaria sp., R. abbreviata, Navicula sp., Navicula sp. 1, Encyonema minutum (Hilse) D. G. Mann, Phacus parvulus G. A. Klebs. According to the NGS data, OTU dominated (64.8\% of the total number of reads), the closest homologue of which with an identity of 99.8\% from database GenBank (NCBI) is Thalassiosira sp. (HM991702.1). The group of subdominants was formed by sequences identified as C. meneghiniana (KT386323.1; similarity 99.8\%), Ochromonas sp. (KY887582.1; similarity 97.0\%), Chlorococcum oleofaciens Trainor \& Bold (MT921629.1; similarity 99.8\%), Ulva sp. (LC131339.1; similarity $99.8 \%$ ).

The taxonomic composition of the microalgae and Cyanobacteria assemblage of the river mouth significantly differed from those of the middle course. 60 taxa of microorganisms (48 taxa of microalgae and $12-$ Cyanobacteria) were identified in the assemblage of microalgae and Cyanobacteria from the mouth of the river. The LM method revealed 13 taxa belonging to 5 phyla: Bacillariophyta (6 species and infraspecies taxa), Chlorophyta (4 species), Cryptophyta (1), Ochrophyta (1), Miozoa (1). The DNA libraries from the sample of river mouth included 45 OTUs corresponding to phyla: Bacillariophyta (18 OTUs), Chlorophyta (10 OTUs), Cryptophyta (9 OTUs), Ochrophyta (3 OTUs), Miozoa (3 OTUs), Haptophyta (1 OTU), Chromista phylum incertae sedis (1 OTU, Fig. 2, 3).

Each of the methods used indicated that the representative of the phylum Cryptophyta ( $99.5 \%$ of the total abundance of algae according LM and $58.7 \%$ of the total number of reads according NGS) was predominant in the assemblage of microalgae of the mouth of the Bolshaya Samoroda River. In addition, according to the results of the NGS, the dominant complex of the river mouth included small-cells algae from the phylum Chlorophyta, identified with a similarity of $99.8 \%$ as Nannochloris sp. (JQ315647.1). They were not detected microscopically. Among the subdominant sequences the Chaetoceros sp. (EF473734.1; similarity 99.8\%), Chaetoceros sp.1 (KX609786.1; similarity 99.8\%) and unclassified Chromista (Chromista phylum incertae sedis) are marked. They were also not detected by morphological analysis.

Morphological and genetic diversity of Cyanobacteria of the Bolshaya Samoroda River. According to the results of morphological analysis, two taxa from the phylum Cyanobacteria - Synechocystis sp. and Johanseninema constrictum (Szafer) Hasler, Dvorák \& Poulícková were found in the water samples of the middle course of the Bolshaya Samoroda River. The assemblage of Cyanobacteria of the river mouth was more diverse and included Oscillatoria sp., Oscillatoria sp. 1, Lyngbya confervoides $\mathrm{C}$. Agardh ex Gomont, Anabaena sphaerica f. conoidea Elenkin. 


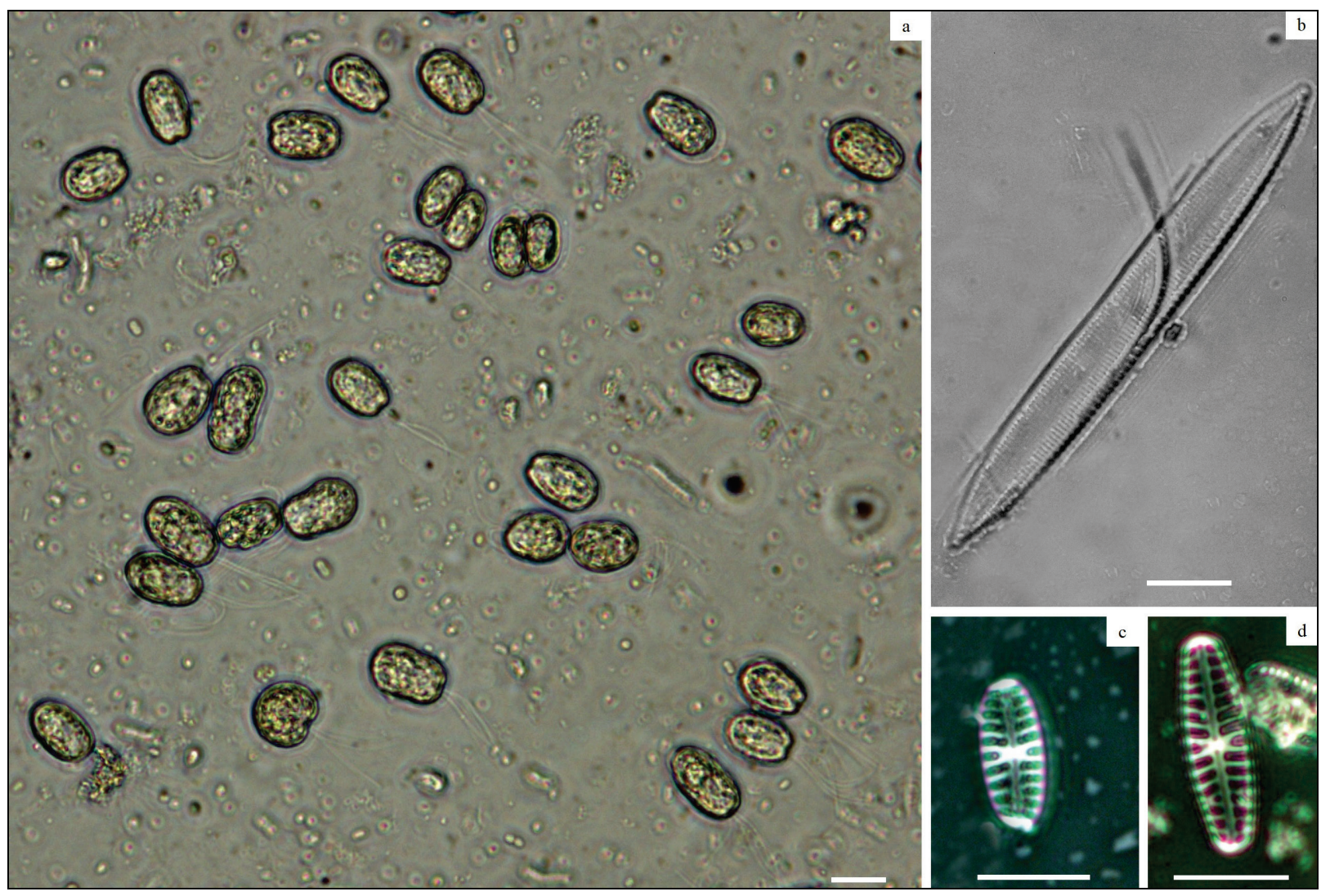

Fig. 4. Predominant taxa of the algae flora in the saline rivers of the Elton Lake Basin: $a$-representatives of the genus Tetraselmis F. Stein of the middle course and mouth of the Malaya Samoroda River; $b-d$-predominant taxa of the middle course of the Bolshaya Samoroda River ( $b$-Tryblionella hungarica; $c, d$-Hippodonta hungarica); scale bars $-10 \mu \mathrm{m}$

According to the NGS data, as well as the LM results, the DNA libraries of the water samples of the mouth of the river was distinguished by a large number of OTUs. 8 OTUs were identified. Five of them were classified as representatives from the order Synechococcales of the family Synechococcaceae and three sequences were identified only at the phylum level. The DNA libraries of the water samples of the middle course included only two unclassified representatives of Cyanobacteria.

Morphological and genetic diversity of microalgae and Cyanobacteria of the Malaya Samoroda River. The algal assemblage of the middle course of the Malaya Samoroda River was represented by 27 taxa, 23 of which were autotrophic protists and 4 - Cyanobacteria. 10 taxa ranked below the genus from the phyla Chlorophyta ( 8 species) and Bacillariophyta (2), as well as 4 taxa of Cyanobacteria were found by LM method. The genetic diversity of microalgae of the middle course of the Malaya Samoroda River was slightly higher. The DNA libraries of the water samples of the middle course included 20 OTUs belonging to the phyla Chlorophyta (17 OTUs, $99.9 \%$ of the total number of reads), Bacillariophyta (2 OTUs) and Cryptophyta (1 OUT, Fig. 5). Only one sequence corresponding to the phylum Cyanobacteria was found with NGS. The closest homologues of this OTU with a similarity $99.0 \%$ in the GenBank database were the sequences deposited: Geitlerinema sp. SAS11146 (KX359357.1) and Phormidium sp. GI08AO (KY363612.1).

It should be noted that the species of algae of the genus Tetraselmis F. Stein, Asteromonas A. Artari, Dunaliella Teodoresco and also Anagnostidinema amphibium (C. Agardh ex Gomont) Strunecký, Bohunická, J. R. Johansen (= Phormidium amphibium (C. Agardh ex Gomont) Anagnostidis \& Komárek, Geitlerinema amphibium (C. Agardh ex Gomont) Anagnostidis) were found simultaneously by both methods.

Representatives of Chlorophyta were the most abundant in the algal assemblage of the middle course of the Malaya Samoroda River (Fig. 4a). The dominant complex, according to LM data, included Tetraselmis arnoldii (Proschkina-Lavrenko) R. E. Norris, Hori \& Chihara, T. tetrathele (West) Butcher, Tetraselmis sp., which together made up $89.4 \%$ of the total abundance of the algal assemblage. The group of subdominants was formed by $T$. cordiformis (H. J. Carter) F. Stein and $T$. contracta
(N. Carter) Butcher. Similar results were obtained by the NGS method. More than a half (12 OTUs) of the total number of OTUs belonged to the genus Tetraselmis (Chlorophyta). At the same time, the absolute predominance ( $96.9 \%$ of the total number of series) of the sequence whose closest homologue in the GenBank database (NCBI) is T. indica Arora \& Anil (HQ651184.3, 100\% identity) was noted.

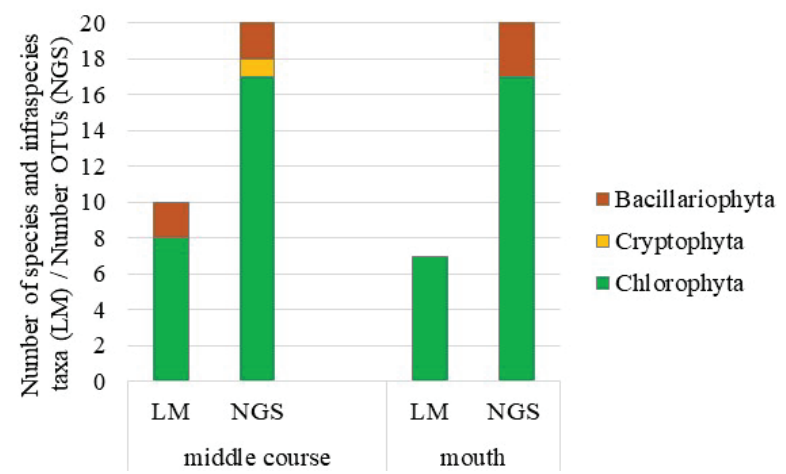

Fig. 5. Species diversity of microalgal assemblages in the Malaya Samoroda River: LM - light microscopy, NGS - next-generation sequencing

The assemblage of microalgae and Cyanobacteria of the mouth of the river didn't differ significantly from the middle course. 24 taxa of microorganisms were found in the algae flora of the river mouth. Among them, 20 taxa were accounted by microalgae of the phyla Chlorophyta and Bacillariophyta and 4 - Cyanobacteria. Here, the representatives of Chlorophyta that belonged to the genus Tetraselmis, as in the algal assemblage of the middle course of the river, were the most abundant. According to LM data, the dominant complex included T. cordiformis, T. arnoldii, T. tetrathele. Chlamydomonas sp. is noted as a subdominant. According to the NGS, $96.0 \%$ of the total number of reads accounted for the sequence whose closest homologue is T. indica (HQ651184.3). 


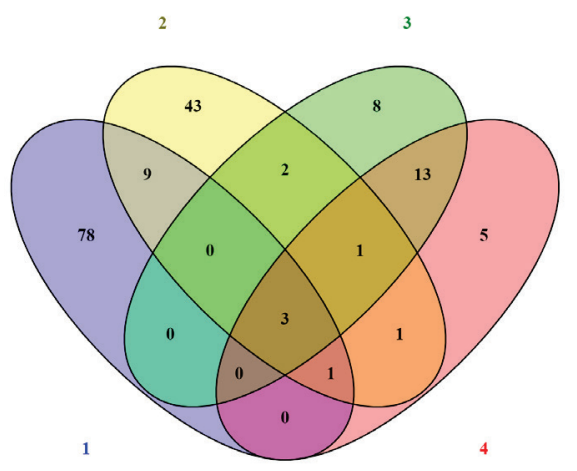

Fig. 6. Venn's diagram showing common and specific taxa of microalgae and Cyanobacteria revealed by light microscopy and nextgeneration sequencing in the Malaya Samoroda River and Bolshaya Samoroda River: 1 -assemblages of microalgae and Cyanobacteria in the middle course of the Bolshaya Samoroda River, 2 -assemblages of microalgae and Cyanobacteria in the mouth of the Bolshaya Samoroda River, 3 - assemblages of microalgae and Cyanobacteria in the middle course of the Malaya Samoroda River, 4 -assemblages of microalgae and Cyanobacteria in the mouth of the Malaya Samoroda River
Comparison of the species diversity of algae flora of the Malava Samoroda River and Bolshaya Samoroda River. Despite the territorial proximity and similar climatic conditions, significant differences in the mineralization level probably determined the specificity of the taxonomic structure and species diversity of the algal communities of the studied watercourses. In general, less species diversity with a pronounced dominance of halophilic species was characterized by the assemblage of microalgae and Cyanobacteria of the Malaya Samoroda River. The comparative analysis showed that only six taxa (Chlamydomonas raudensis Ettl, Chaetoceros sp., H. phi, Dunaliella sp., Nannochloris sp., T. cordiformis (LM) / T. indica (NGS) were common to the algae flora of the studied rivers, and only three of them (Dunaliella sp., Nannochloris sp., T. cordiformis (LM) / T. indica (NGS) were registered at each point of sampling (Fig. 6).

Compared to the previously reported data (Burkova, 2012, 2015; Gorokhova \& Zinchenko, 2014; Yatsenko-Stepanova et al., 2015; Selivanova et al., 2019) our study revealed new taxa for the algae flora of the saline Elton rivers. Thus, 18 taxa belonging to the phyla Chlorophyta (5), Ochrophyta (4), Euglenozoa (4), Cryptophyta (3), Haptophyta (1), Cyanobacteria (1) have been recorded in the Bolshaya Samoroda River for the first time. Seven taxa have been detected for the first time in the algal and cyanobacterial assemblages of the Malaya Samoroda River from the phyla Chlorophyta (4), Cryptophyta (1), and Cyanobacteria (2) (Table 1).

Table 1

New taxa for the algae flora in the saline rivers of the Elton Lake Basin

\begin{tabular}{|c|c|c|c|c|}
\hline \multirow[b]{2}{*}{ Taxa } & \multirow[b]{2}{*}{ Locality } & \multirow[b]{2}{*}{$\mathrm{LM}$} & \multicolumn{2}{|l|}{ NGS } \\
\hline & & & Closest homologue (accession no.) in the GenBank database & $\begin{array}{l}\text { Simila- } \\
\text { rity }(\%)\end{array}$ \\
\hline Euglena bucharica I. Kisselev & B.S.R., m.c. & + & - & - \\
\hline Lepocinclis tripteris (Dujardin) B. Marin \& Melkonian & B.S.R., m.c. & + & - & - \\
\hline Phacus orbicularis K. Hübner & B.S.R., m.c. & + & - & - \\
\hline Ph.parvulus G. A. Klebs & B.S.R., m.c. & + & - & - \\
\hline Pseudocharaciopsis ovalis (Chodat) D. J. Hibberd & B.S.R., m.c. & - & Pseudocharaciopsis ovalis (KF848932.1) & 99.1 \\
\hline Characiopsis sp. & B.S.R., m.c. & - & Characiopsis saccata (KY271645.1) & 99.5 \\
\hline Poterioochromonas stipitata Scherffel & B.S.R., m.c. & - & Poterioochromonas stipitata (MH536657.1) & 100.0 \\
\hline Chrysolepidomonas sp. & B.S.R., m.c. & - & Chrysolepidomonas dendrolepidota (AF123297.1) & 97.6 \\
\hline Pavlova sp. & B.S.R., m.c. & - & Pavlovagranifera & 97.0 \\
\hline Hemiselmis cryptochromatica C. E. Lane \& J. M. Archibald & B.S.R., m. & - & Hemiselmis cryptochromatica (KY980198.1) & 99.5 \\
\hline Rhodomonas sp. & B.S.R., m. & - & Rhodomonas atrorosea (MG022759.1) & 99.8 \\
\hline Hanusia phi J. A. Deane & $\begin{array}{l}\text { B.S.R., m.; } \\
\text { M.S.R., m.c. }\end{array}$ & + & Hanusia phi (U53126.1) & 99.8 \\
\hline Borodinellopsis sp. & B.S.R., m.c. & - & Borodinellopsis texensis(KM020129.1) & 98.1 \\
\hline Chlorochytrium lemnae Cohn & B.S.R., m.c. & - & Chlorochytrium lemnae (HE860249.1) & 98.8 \\
\hline Caespitella $\mathrm{sp}$ & B.S.R., m.c. & - & Caespitella pascheri (LN870281.1) & 99.5 \\
\hline Halochlorococcum sp. & B.S.R., m.c. & - & Halochlorococcum porphyrae (DQ821520.2) & 99.3 \\
\hline Tetraselmis cordiformis (H. J. Carter) F. Stein & $\begin{array}{l}\text { B.S.R., m.c., m.; } \\
\text { M.S.R., m.c., m. }\end{array}$ & + & Tetraselmis sp. MA-2011 (T. indica) (HQ651184.1) & 100.0 \\
\hline T. arnoldii (Proschkina-Lavrenko) R. E. Norris, Hori \& Chihara & M.S.R., m.c., m. & + & Tetraselmis sp. MA-2011 (T. indica) (HQ651184.1) & 100.0 \\
\hline T. tetrathele (West) Butcher & M.S.R., m.c., m. & + & Tetraselmis sp. MA-2011 (T. indica) (HQ651184.1) & 100.0 \\
\hline Pyrobotrys elongatus Korshikov & M.S.R., m.c. & - & Pyrobotrys elongatus (LC093468.1) & 99.0 \\
\hline Oscillatoria simplicissima Gomont & M.S.R., m.c., m. & + & - & - \\
\hline Synechococcus elongatus (Nägeli) Nägeli & M.S.R., m.c., m. & + & - & - \\
\hline Johanseninema constrictum (Szafer) Hasler, Dvorák \& Poulícková & B.S.R., m.c. & + & - & - \\
\hline
\end{tabular}

Notes: B.S.R. - Bolshaya Samoroda River, M.S.R. - Malaya Samoroda River, m.c. - middle course, m. - mouth, LM- light microscopy, NGS - next-generation sequencing.

\section{Discussion}

This study represents one of the first comparative analyses of taxonomic structure and species diversity of microalgae and Cyanobacteria of the saline Elton rivers employing both morphology-based and molecular methods.

It should be noted that in all the samples that we studied the genetic diversity significantly exceeded the diversity estimated by LM method. This is also indicated by other authors who conducted studies using the traditional morphological method and high-throughput sequencing (Groendahl et al., 2017; Rivera et al., 2018a, b; Gao et al., 2018). One of the reasons for the observed differences may be the high sensitivity of the NGS method, which allows detection of low-abundance taxa (Groendahl et al., 2017). Thus, only four genera of microorganisms were registered by both methods in the assemblage of microalgae and Cyanobacteria of the middle course of the Malaya Samoroda River, while Achnanthidium sp.,
Chaetoceros sp., Chlamydomonas raudensis Ettl, Pyrobotrys elongatus, Nannochloris sp., $H$. phi were identified only according to NGS. The abundance of these taxa was small and didn't exceed $0.1 \%$ of reads. Similarly, Pedinellales sp., Pseudocharaciopsis ovalis (Chodat) D. J. Hibberd, Poterioochromonas stipitata, Halochlorococcum sp., Pavlova sp., Chroomonas sp. in the algal assemblage of the middle course of the Bolshaya Samoroda River were revealed only by NGS. The abundance of these species also didn't exceed $0.1 \%$ of reads. In addition, as noted earlier, the NGS method is effective in detecting small-cell forms of the picoplankton fraction (Belevich et al., 2015; Rivera et al., 2018a). Detection and identification of picoalgae $(0.2-2.0 \mu \mathrm{m})$ by the morphological method can be difficult or impossible due to their extremely small size, which ultimately leads to an underestimation of the species diversity of the algae flora of the waterbody (Belevich et al., 2015). Our results are consistent with the data described above. For example, the picoplankton alga Nannochloris sp. was detected by us in each sample only with NGS and was not found 
microscopically. At the same time, it should be noted that the Euglenozoa registered in the assemblage of microalgae of the middle course of the Bolshaya Samoroda River by morphological analysis were not detected by high-throughput sequencing. This discrepancy may be due to the use of universal primers, which (compared to selective primer pairs) due to insufficient coverage reveal only half of the OTUs (Lentendu et al., 2014; Selivanova et al., 2019). In addition, the use of universal primers does not allow for a clear differentiation of species within the genus (Arora et al., 2013). So, for example, DNA libraries of the water samples of the middle course and the mouth of the Malaya Samoroda River included a sequence identified as Dunaliella sp. The closest homologues of this OTU with a similarity $99.0 \%$ in the GenBank database were the sequences such as Dunaliella primolecta strain SAG 183.80 (KR607494.1), D. salina strain SAG 184.80 (KR607493.1), D. tertiolecta strain SAG 13.86 (EF473737.1), D. parva strain SAG 19-1 (DQ009763.1). For the same reason, 12 OTUs in the DNA libraries of the water samples of the middle course and the mouth of the Malaya Samoroda River were identified only as Tetraselmis sp.

It is also noteworthy that the complex of dominants and subdominants of the algal assemblage of the middle course of the Bolshaya Samoroda River, characterized by the NGS, significantly differed from the similar one estimated by the LM. Thalassiosira sp. predominated in the algae assemblage according to the results of the NGS. Whereas according to the LM data, pennate diatoms (H. capitate, T. hungarica) dominated, and centric forms were represented by single specimens. The revealed differences probably may be related with the detection of "extracellular" DNA extracted from dead cells and capable of persisting for a long time in aquatic ecosystems (Pawlowski et al., 2018). On the other hand, the LM method is also not devoid of error. The diatomic analysis could take into account the forms represented by frustules of dead diatoms, which, due to their siliceous composition, can be retained for a long time in the reservoir (Rivera et al., 2018b; Selivanova et al., 2019). This can be confirmed by the fact that, for example, Navicula sp. and Nitzschia sp. were detected in the assemblage of microalgae of the middle course of the Malaya Samoroda River only by the LM method, but they were not registered with NGS.

At the same time, it should be noted that the dominant species of the mouth of the Bolshaya Samoroda River identified by us as Cryptophyceae sp., according to the LM data, has a morphological similarity with the predominant according to the NGS data Hanusia phi J. A. Deane (U53126.1). The first description of the $H$. phi is given in Deane et al. (1998). Thus, the length of the algae cells which we found varies from 7 to $10 \mu \mathrm{m}$, and the width is $5 \mu \mathrm{m}$. There are two flagella at the anterior end of the cell at the base of the reservoir (furrow). The reservoir (furrow) is lined with ejectisomes and reaches to the middle of the cell. The shape of the cell is obovate with a truncated anterior end. The posterior end of the cell is somewhat drawn back, forming a narrow tail, which according to Deane et al. (1998) was observed in H. phi during the period of intensive growth of the culture. Morphological similarity between a species which we found and $H$. phi allows us to conclude that the data about a dominant species estimated by the LM and NGS methods are comparable.

It should also be noted that in all previous studies performed using the LM method (Burkova, 2012, 2016; Yatsenko-Stepanova et al., 2015; Gorokhova, 2018), representatives of golden algae (Chrysophyceae) were not identified in the algae flora of saline Elton rivers, with the exception of Salpingoeca freguentissima (Zacharias) Lemmermann (Burkova, 2016). But, now, according to modern taxonomy, S. freguentissima is classified as a heterotrophic flagellate of the class Choanoflagellatea (Protozoa) (Guiry \& Guiry, 2021). The integrated approach used by us allowed us to characterize the diversity of Chrysophyceae of the studied watercourses. Microorganisms of this class were registered only in the algal communities of the Bolshaya Samoroda River, which probably indicates their limited range of halotolerance and their inability to exist in hyperhaline conditions. The main part of the Chrysophyceae was identified by the NGS method (total 8 sequences, six of which were identified at the genus level as $O c h-$ romonas sp., and also Chrysolepidomonas sp. and Chromulina sp.) and only one taxon (Pseudokephyrion entzii W. Conrad) has been detected by LM. Similarly, for the first time the representatives of Xanthophyceae (Characiopsis sp.) and Haptophyta (Pavlova sp.) were found in communities of the mouth and middle course of the Bolshaya Samoroda River by
NGS. Thus, it should be emphasized that each of the methods under consideration has its own specific disadvantages. At the same time, the use of the NGS method in combination with the traditional morphological method in the analysis of algae biodiversity increases the reliability of the results obtained.

A comparison of the species diversity of the algae flora of the Bolshaya Samoroda and Malaya Samoroda Rivers revealed an extremely low level of similarity ( 6 common taxa). Communities of microalgae and Cyanobacteria of the Bolshaya Samoroda River (mixohaline river) were characterized by high species diversity, whereas the algae flora of the hyperhaline Malaya Samoroda River was represented by only three phyla of microalgae and Cyanobacteria. Our results are in good agreement with the data of other authors, which also indicate decrease in species richness and simplification of the structure of algae flora in hyperhaline conditions (Gorokhova \& Zinchenko, 2014; Afonina \& Tashlykova, 2016; Skarlato $\&$ Telesh, 2017). Only three taxa were identified in each point of sampling (in the range of salinity from 10 to 85 ppt). These are Dunaliella sp., Nannochloris sp., T. cordiformis (LM)/T. indica (NGS). Algae of the above genera are well studied, as they are considered today as promising sources of carotenoids and polyunsaturated fatty acids (Solovchenko et al., 2015; Mohammadi et al., 2015; Almutairi \& Toulibah, 2017). In particular, extensive material has been accumulated indicating a wide range of halotolerances of these algae (Masyuk et al., 2007; Saadaoui et al., 2016; Ishika et al., 2018), which explains their detection at each point of sampling.

\section{Conclusion}

Thus, for the first time, an assessment was made of the species diversity of the assemblages of microalgae and Cyanobacteria of the saline rivers of the Elton Lake Basin (Malaya Samoroda River and Bolshaya Samoroda River) by a combined approach using morphological analysis and high-throughput sequencing. The species diversity revealed with NGS was higher compared to that estimated by the morphological method. Next-generation sequencing allowed us to refine and expand the list of microalgae taxa in the studied saline rivers due to detection of difficult species to identify, low-abundance taxa, as well as extremely small-cell forms. Generally, 91 taxa of microorganisms were identified by integrated approach in the assemblages of microalgae and Cyanobacteria in the middle course of the Bolshaya Samoroda River, and 60 taxa - in the river mouth. The species diversity of those assemblages in the hypersaline Malaya Samoroda River was lower: 27 taxa from the middle course and 23 taxa from the mouth. Eighteen taxa have been recorded for the first time in the Bolshaya Samoroda River, belonging to the phyla Chlorophyta (5), Ochrophyta (4), Euglenozoa (4), Cryptophyta (3), Haptophyta (1), Cyanobacteria (1). Seven taxa have been detected for the first time in the algal and cyanobacterial assemblages of the Malaya Samoroda River from the phyla Chlorophyta (4), Cryptophyta (1), and Cyanobacteria (2). Some discrepancies between the data obtained by light microscopy and next-generation sequencing indicate the advantage of simultaneous use of both methods for study of algae communities.

The authors are grateful to Prof. T. D. Zinchenko (Institute of Ecology of the Volga River Basin of the Russian Academy of Sciences) for arrangement of the field research expedition, as well as to A. O. Plotnikov $\mathrm{PhD}, \mathrm{MD}$ (Institute for Cellular and Intracellular Symbiosis of the Ural Branch of the Russian Academy of Sciences) for sampling and sequencing, to $\mathrm{E}$. A. Gerasimova $\mathrm{PhD}$ (Institute for Cellular and Intracellular Symbiosis of the Ural Branch of the Russian Academy of Sciences) for preparation of DNA libraries. The study was performed in the Center of Shared Scientific Equipment "Persistence of Microorganisms" of the Institute for Cellular and Intracellular Symbiosis of the Ural Branch of the Russian Academy of Sciences, Orenburg, Russia.

\section{References}

Afonina, E. Y., \& Tashlykova, N. A. (2018). Plankton community and the relationship with the environment in saline lakes of Onon-Torey plain, Northeastern Mongolia. Saudi Journal of Biological Sciences, 25, 399-408.

Almutairi, A. W., \& Toulibah, H. E. (2017). Effect of salinity and pH on fatty acid profile of the green algae Tetraselmis suecica. Journal of Petroleum and Environmental Biotechnology, 8(3), 1-6. 
Arora, M., Anil, A. C., Leliaert, F., Delany, J., \& Mesbahi, E. (2013). Tetraselmis indica (Chlorodendrophyceae, Chlorophyta), a new species isolated from salt pans in Goa, India. European Journal of Phycology, 48(1), 61-78.

Bel'kova, N. L., Dzyuba, E. V., Sukhanova, E. V., \& Khanaeva, T. A. (2008). Adaptaciya metodov molekulyarno-geneticheskogo analiza dlya izucheniya mikroorganizmov, associirovannyh s rybami [Adaptation of molecular genetic methods to study microorganisms associated with fish]. Inland Water Biology, 1(2), 192-195 (in Russian).

Belevich, T. A., Ilyash, L. V., Milyutina, I. A., Logacheva, M. D., Goryunov, D. V., \& Troitsky, A. V. (2015). Metagenomika pikovodoroslej Belogo morya: Pervye dannye [Metagenomic analyses of White Sea picoalgae: First data]. Biochemistry, 80(11), 1514-1521 (in Russian).

Burkova, T. N. (2016). Taksonomicheskaya harakteristika fitoplanktona vysokomineralizovannoj reki Bol'shaya Smorogda (Priel'ton'e) [Taxonomic characteristics of phytoplankton river Big Smorogda with high-mineral waters (Lake Elton's plain)]. Samarskaya Luka: Problems of regional and global ecology, 25(1), 131-138 (in Russian).

Burkova, T. N. (2012). Fitoplankton mineralizovannoj reki Malaya Samoroda (ozero Elton) [Phytoplankton of the saline River Malaya Smorogda (Lake Elton)]. Materials of the reports of the II All-Russian Scientific Conference with international participation "Small rivers: Ecological state and prospects of development". Cheboksary, 70-74 (in Russian).

Burkova, T. N. (2015). Aal'goflora planktona vysokomineralizovannoj reki Bol'shaya Smorogda (Priel'ton'e) [Algae flora of saline plankton of the River Bolshaya Smorogda (Lake Elton)]. Proceedings of the Samara Scientific Center, 17(4), 745-748 (in Russian).

Deane, J., Hill, D., Brett, S., \& McFadden, G. (1998). Hanusia phi gen. et sp. nov. (Cryptophyceae): Characterization of 'Cryptomonas sp. $\Phi$ '. European Journal of Phycology, 33(2), 149-154.

Edgar, R. C. (2013). UPARSE: Highly accurate OTU sequences from microbial amplicon reads. Nature Methods, 10,996-998

Gao, W., Chen, Z., Li, Y., Pan, Y., Zhu, J., Guo, S., Hu, L., \& Huang, J. (2018). Bioassessment of a drinking water reservoir using plankton: High throughput sequencing vs. traditional morphological method. Water, 10(1), 82.

Gorokhova, O. G. (2018). Al'goflora rek bassejna gipergalinnogo ozera Elton [Flora algae rivers tributaries salt Lake Elton]. In: Environmental problems of large river basins -6 ”. Materials of the international conference. Pp. 81-83 (in Russian)

Gorokhova, O. G., \& Zinchenko, T. D. (2014). Fitoplankton vysokomineralizovannyh rek Priel'ton'ya [Phytoplankton of the highly mineralized rivers of the Lake Elton basin]. Proceedings of the Samara scientific center, Russian Academy of Sciences, 16(5), 1715-1721 (in Russian).

Gorokhova, O. G., \& Zinchenko, T. D. (2016). Raznoobrazie i struktura soobshchestv fitoplanktona vysokomingeralizovannyh rek bassejna ozera El'ton [Diversity and structure of phytoplankton communities in highly mineralized rivers of the Lake Elton basin]. Water: Chemistry and Ecology, 11, 58-65 (in Russian).

Groendahl, S., Kahlert, M., \& Fink, P. (2017). The best of both worlds: A combined approach for analyzing microalgal diversity via metabarcoding and morphology-based methods. PLoS One, 12(2), e0172808.

Guiry, M. D., \& Guiry, G. M. (2021). AlgaeBase. World-wide electronic publication, National University of Ireland, Galway.

Gusakov V. A. (2019). Donnaya mejofauna vysokomineralizovannyh rek prirodnogo parka 'El'tonskij”' (Rossiya) [Bottom meiofauna of highly mineralised rivers in the Eltonsky Nature Park (Russia)]. Nature Conservation Research, 4(1), 3763 (in Russian).

Gutiérrez-Cánovas, C., Arribas, P., Naselli-Flores, L., Bennas, N., Finocchiaro, M., Millán, A., \& Velasco, J. (2019). Evaluating anthropogenic impacts on naturally stressed ecosystems: Revisiting river classifications and biomonitoring metrics along salinity gradients. Science of the Total Environment, 658, 912-921.

Hašler, P., Dvořak, P., Johansen, J., Kitner M., Ondřej, V., \& Pouličkova, A. (2012) Morphological and molecular study of epipelic filamentous genera Phormidium, Microcoleus and Geitlerinema (Oscillatoriales, Cyanophyta/Cyanobacteria). Fottea, a Journal of the Czech Phycological Society, 12(2), 341-356.

Heidelberg, K. B., Nelson, W. C., Holm, J. B., Eisenkolb, N., Andrade, K., \& Emerson, J. B. (2013). Characterization of eukaryotic microbial diversity in hypersaline Lake Tyrrell, Australia. Frontiers in Microbiology, 4, 115.

Ishika, T., Bahri, P. A., Laird, D. W., \& Moheimani, N. R. (2018). The effect of gradual increase in salinity on the biomass productivity and biochemical composition of several marine, halotolerant, and halophilic microalgae. Journal of Applied Phycology, 30, 1453-1464.

Kim, K. M., Park, J.-H., Bhattacharya, D., \& Yoon, H. S. (2014). Applications of next-generation sequencing to unravelling the evolutionary history of algae. International Journal of Systematic and Evolutionary Microbiology, 64, 333-345.

Klindworth, A., Pruesse, E., Schweer, T., Peplies, J., Quast, C., Horn, M., \& Glöckner, F. O. (2013). Evaluation of general 16S ribosomal RNA gene PCR primers for classical and next-generation sequencing-based diversity studies. Nucleic Acids Research, 41(1), e1.
Komárek, J., Kaštovský, J., Mareš, J., \& Johansen, J. R. (2014). Taxonomic classification of cyanoprokaryotes (cyanobacterial genera) 2014, using a polyphasic approach. Preslia, 86, 295-335.

Krakhmalny, A. F. (2011). Dinofitovye vodorosli Ukrainy (Illyustrirovannyj opredelitel') [Dinophyta of Ukraine (Illustrated book for identification)]. Alterpres, Kiev (in Russian).

Krammer, K., \& Lange-Bertalot, H. (1986). Bacillariophyceae. 1. Teil: Naviculaceae. Süßwasserflora von Mitteleuropa 2/1. Gustav Fisher Verlag, Jena (in German).

Krammer, K., \& Lange-Bertalot, H. (1988). Bacillariophyceae. 2. Teil: Bacillariaceae, Epithemiaceae, Surirellaceae. Süßwasserflora von Mitteleuropa 2/2. Gustav Fisher Verlag, Jena (in German).

Krammer, K., \& Lange-Bertalot, H. (1991a). Bacillariophyceae. 3. Teil: Centrales, Fragilariaceae, Eunotiaceae. Süßwasserflora von Mitteleuropa 2/3. Gustav Fischer Verlag, Stuttgart; Jena (in German).

Krammer, K., \& Lange-Bertalot, H. (1991b). Bacillariophyceae. 4. Teil: Achnanthaceae, kritische Ergänzungen zu Navicula (Lineolatae) und Gomphonema. Gesamtliteraturverzeichnis. Süßwasserflora von Mitteleuropa 2/4. Gustav Fischer Verlag, Stuttgart (in German)

Kulikovskiy, M. S., Gusev, E. S., Andreeva, S. A., \& Annenkova, N. V. (2014). Phylogenetic position of the diatom genus Geissleria Lange-Bertalot et Metzeltin and description of two new species from Siberian mountain lakes. Phytotaxa, 177(2), 249-260.

Lentendu, G., Wubet, T., Chatzinotas, A, Wilhelm C, Buscot, F, \& Schlegel, M. (2014). Effects of long-term differential fertilization on eukaryotic microbial communities in an arable soil: A multiple barcoding approach. Molecular Ecology, 23(13), 3341-3355.

Lin, G., Chai, J., Yuan, S., Mai, C., Cai, L., Murphy, R. W., Zhou, W., \& Luo, J. (2016). VennPainter: A tool for the comparison and identification of candidate genes based on Venn diagrams. PLoS One, 11(4), e0154315.

Liu, Y., Yao, T., Jiao, N., Kang, S., Xu, B., Zeng, Y., Huang, S., \& Liu, X. (2009). Bacterial diversity in the snow over Tibetan Plateau Glaciers. Extremophiles, $13,411-423$

Manoylov, K. M. (2014). Taxonomic identification of algae (morphological and molecular): Species concepts, methodologies, and their implications for ecological bioassessment. Journal of Phycology, 50, 409-424.

Manoylov, K. M., France, Y. E., Geletu, A., \& Dominy, J. N. (Jr.). (2016). Algal community membership of estuarine mudflats from the savannah river, United States. Journal of Marine Science and Engineering, 4(1), 11

Masyuk, N. P., \& Lilitskaya, G. G. (2006). Chlorodendrophyceae class. nov. (Chlorophyta, Viridiplantae) in the flora of Ukraine. II. The Genus Tetraselmis F. Stein. Ukjrainskii Botanicheskii Jumal, 63(6), 741-758 (in Ukrainian).

Masyuk, N. P., Posudin, Y. I., \& Lilitskaya, G. G. (2007). Fotodvizhzenie kletok Dunaliella Teod. (Dunaliellales, Chlorophyceae, Viridiplantae) [Photomovement of Dunaliella Teod. cells (Dunaliellales, Chlorophyceae, Viridiplantae)] Kiev (in Russian).

Medlin, L. K. (2018). Mini review: Diatom species as seen through a molecular window. Brazilian Journal of Botany, 41, 457-469.

Millán, A., Velasco, J, Gutiérrez-Cánovas, C., Arribas, P., Picazo, F, Sánchez-Fernández, D., \& Abellán, P. (2011). Mediterranean saline streams in Southeas Spain: What do we know? Journal of Arid Environments, 75, 1352-1359.

Mohammadi, M., Kazeroni, N., \& Baboli, M. J. (2015). Fatty acid composition of the marine micro alga Tetraselmis chuii Butcher in response to culture conditions. Journal of Algal Biomass Utilization, 6(2), 49-55.

Oliveira, M. C., Repetti, S. I., Iha, C., Jackson, C. J., Díaz-Tapia, P., Lubiana, K. M. F., Cassano, V., Costa, J. F., Cremen, M. C. M., Marcelino, V. R., \& Verbruggen, H. (2018). High-throughput sequencing for algal systematic. European Journal of Phycology, 53(3), 256-272.

Orfeo, O. (1999). Sedimentological characteristics of small rivers with loessic headwaters in the Chaco, South America. Quaternary International, 62, 69-74.

Palinska, K. A., Vogt, J. C., \& Surosz, W. (2018). Biodiversity analysis of the unique geothermal microbial ecosystem of the Blue Lagoon (Iceland) using nextgeneration sequencing (NGS). Hydrobiologia, 811, 93-102.

Pawlowski, J, Kelly-Quinn, M, Altermatt, F, Apothéloz-Perret-Gentil, L, Beja, P Boggero, A., Borja, A., Bouchez, A., Cordier, T., Domaizon, I., Feio, M. J., Filipe, A. F., Fornaroli, R., Graf, W., Herder, J., Hoom, B., Jones, J. I., SagovaMareckova, M., Moritz, C., Barquín, J., Piggott, J. J., Pinna, M., Rimet, F., Rinkevich, B., Sousa-Santos, C., Specchia, V., Trobajo, R., Vasselon, V., Vitecek, S., Zimmerman, J., Weigand, A., Leese, F., \& Kahlert, M. (2018). The future of biotic indices in the ecogenomic era: Integrating (e)DNA metabarcoding in biological assessment of aquatic ecosystems. Science of the Total Environment, $637-638,1295-1310$

Rivera, S. F., Vasselon, V., Ballorain, K., Carpentier, A., Wetzel, C. E., Ector, L., Bouchez, A., \& Rimet, F. (2018a). DNA metabarcoding and microscopic analyses of sea turtles' biofilms: Complementary to understand turtle behavior. PLoS One, 13(4), e0195770 
Rivera, S. F., Vasselon, V., Jacquet, S., Bouchez, A., Ariztegui, D., \& Rimet, F. (2018b). Metabarcoding of lake benthic diatoms: From structure assemblages to ecological assessment. Hydrobiologia, 807, 37-51.

Saadaoui, I., Ghazal, G. A., Bounnit, T., Khulaifi, F. A., Jabri, H. A., \& Potts, M. (2016). Evidence of thermo and halotolerant Nannochloris isolate suitable for biodiesel production in Qatar Culture Collection of Cyanobacteria and Microalgae. Algal Research, 14, 39- 47.

Selivanova, E. A., Ignatenko, M. E., Yatsenko-Stepanova, T. N., \& Plotnikov, A. O. (2019). Diatom assemblages of the brackish Bolshaya Samoroda River (Russia) studied via light microscopy and DNA metabarcoding. Protistology, 13(4), 215-235.

Shitikov, V. K., Rosenberg, G. S., \& Zinchenko, T. D. (2003). Kolichestvennaya gidroekologiya: Metody sistemnoj identifikacii [Quantitative hydroecology: Methods of system identification]. IEWB RAS, Togliatti (in Russian)

Skarlato, S. O., \& Telesh, I. V. (2017). Razvitie koncepcii maksimal'nogo raznoobraziya protistov v zone kriticheskoj solenosti vody [Development of the concept of maximum diversity of protists in the zone of critical salinity of water]. Biology of the Sea, 43(1), 3-14 (in Russian).

Solovchenko, A. E., Selivanova, E. A., Chekanov, K. A., Sidorov, R. A., Nemtseva, N. V., \& Lobakova, E. S. (2015). Indukciya vtorichnogo karotinogeneza u novyh galofil'nyh mikrovodoroslej iz roda Dunaliella (Chlorophyceae) [Induction of secondary carotenogenesis in new halophile microalgae from genus Dunaliella (Chlorophyceae). Biochemistry, 80, 1508-1513 (in Russian).

Telesh, I., Schubert, H., \& Skarlato, S. (2013). Life in the salinity gradient: Discovering mechanisms behind a new biodiversity pattern. Estuarine, Coastal and Shelf Science, 135, 317-327.
Tsarenko, P. M. (1990). Opredelitel' hlorokokkovyh vodoroslej Ukrainskoj SSR [Determinant of Chlorococcal algae of the Ukrainian SSR]. Naukova Dumka, Kiev (in Russian).

Vasser, S. P., Kondratyeva, N. V., Masyuk, N. P., Palamar-Mordvintseva, G. M. Vetrova, Z. I., Kordyum, E. L., Moshkova, N. A., Prikhodkova, L. P., Kovalenko, O. V., Stupina, V. V., Tsarenko, P. M., Junger, V. P., Radchenko, M. I., Vinogradova, O. N., Bukhtiyarova, L. N., \& Razumna, L. F. (1989). Vodorosli. Spravochnik [Algae. Guide]. Naukova Dumka, Kiev (in Russian).

Wangensteen, O. S., Palacín, C., Guardiola, M., \& Turon, X. (2018). DNA metabarcoding of littoral hardbottom communities: High diversity and database gaps revealed by two molecular markers. PeerJ, 6, e4705.

Yatsenko-Stepanova, T. N., Ignatenko, M. E., Nemtseva, N. V., \& Gorokhova, O. G. (2015). Avtotrofnye mikroorganizmy ust'evyh uchastkov vodotokov sistemy ozera El'ton [Autotrophic microorganisms of the mouth parts of the watercourses in the system of Lake Elton]. Arid Ecosystems, 21(2), 47-54 (in Russian).

Zhan, A., Hulak, M., Sylvester, F., Huang, X., Adebayo, A. A., Abbott, C. L., Adamowicz, S. J., Heath, D. D., Cristescu, M. E., \& MacIsaac, H. J. (2013). High sensitivity of 454 pyrosequencing for detection of rare species in aquatic communities. Methods in Ecology and Evolution, 4, 558-565.

Zhang, J., Kobert, K., Flouri, T., \& Stamatakis, A. (2014). PEAR: A fast and accurate illumina paired-end read merger. Bioinformatics, 30(5), 614-620.

Zinchenko, T. D., Golovatyuk, L. V., Abrosimova, E. V., \& Popchenko, T. V. (2017). Macrozoobenthos in saline rivers in the Lake Elton Basin: Spatial and temporal dynamics. Inland Water Biology, 10(4), 384-398. 